УДК $378.1-043.86(477) “ 20 ” 1045$

DOI:

Інна Шоробура, доктор педагогічних наук, професор, ректор Хмельницької гуманітарно-педагогічної академї

\title{
КОНЦЕПТУАЛЬНІ НАПРЯМИ РОЗВИТКУ ВИЩОЇ ОСВІТИ В УКРАЇНІ У КОНТЕКСТІ ЄВРОПЕЙСЬКОЇ ІНТЕГРАЦІЇ
}

У статті розкрито концептуальні напрями розвитку вищої освіти Украӥни у контексті Свроінтеграції. Звернено увагу на такі аспекти, як створення рівних можливостей у здобутті вищої освіти, оновлення змісту, форм організачії освітнього процесу, запровадження сучасних інновацій, інформачійних технологій та ін. Визначено шляхи реалізації вищезазначених напрямів, як-от: перехід до ступеневої підготовки фахівиів, формування мережі закладів вищої освіти, створення умов для навчання протягом жстття, забезпечення мобільності на ринку прачі та ін. Акцентовано на ідеях Болонського прочесу в Украӥні, забезпечення якості вищої освіти, використання інновачійних підходів у викладанні та навчанні. Це, зокрема, дуальна освіта, дистаниійна освіта та змімане навчання.

Ключові слова: вища освіта в Украӥні; євроінтеграція; концептуальні напрями; Болонський процес; підготовка фахівиів.

Jim. 5.

Inna Shorobura, Doctor of Sciences (Pedagogy), Professor, Rector of Khmelnytskiy Humanitarian Pedagogical Academy

\section{CONCEPTUALAREAS OF HIGHER EDUCATION DEVELOPMENT IN UKRAINE IN THE CONTEXT OF EUROPEAN INTEGRATION}

The article reveals the conceptual areas of development of higher education in Ukraine in the context of European integration. The attention is paid to such aspects as creation of equal opportunities in obtaining higher education, updating of the content, forms of organization of educational process, introduction of modern innovations, information technologies, etc. The ways of realization of the aforementioned areas have been determined, for example: transition to stage system of training specialists, formation of the network of institutions of higher education, creation of conditions for lifelong learning, ensuring mobility in the labour market, etc. The emphasis is on the ideas of the Bologna Process in Ukraine, the quality of higher education, the use of innovative approaches in teaching and learning. This is, in particular, dual education, distance education and mixed learning.

The XXIst century put forward new demands for higher education, and also provides new opportunities for educational activity. First of all, it is connected with modern information technologies, computer technology used as a means of acquiring computer literacy, as a means of studying subjects, as a way to knowledge and experience of mankind, and as a means of distance learning. The need to legalize the plurality of educational trajectories, variation of methods (case-system, training technology, tutoring, facilitation, moderation) becomes organic.

Higher education in the XXIst century is not only the provision of knowledge and education of the individual. Education in the era of globalization and high technologies is a factor in social stability, economic prosperity, competitiveness and national security. The important direction for the development of higher education is the appreciation of the dignity of a teacher, a scientist, an intellectual as one of the requirements of the philosophy of the XXIst century.

Keywords: higher education in Ukraine; European integration; conceptual directions; Bologna process; training of specialists.

П остановка проблеми в загальному вигляді. На сучасному етапі в Україні затверджено Стратегію інтеграції вищої освіти до Європейської освітньої системи в умовах приєднання до Болонського процесу.

Основними напрямами культурно-освітньої і науково-технічної інтеграції визначено впровадження європейських норм і стандартів в освіті, науці й техніці, поширення власних культурних і науково-технічних здобутків у СС.

Здійснення цього завдання передбачає взаємне зняття будь-яких принципових обмежень на контакт і обміни, на поширення інформації. Особливо важливим є здійснення спільних наукових, культурних, освітніх та інших проектів, залучення українських вчених та фахівців до загальноєвропейських програм наукових досліджень.

Незважаючи на досягнення освіти, в умовах нової соціополітичної системи України, вона ще не забезпечує потрібної якості. Чимало випускників закладів вищої освіти не досягли належного рівня конкурентоспроможності на європейському ринку праці. Це зобов'язує глибше 


\section{КОНЦЕПТУАЛЬНІ НАПРЯМИ РОЗВИТКУ ВИЩОЇ ОСВІТИ В УКРАЇНІ У КОНТЕКСТІ ЄВРОПЕЙСЬКОӤ ІНТЕГРАЦІЇ}

аналізувати тенденції в європейській та світовій вищій освіті. Необхідність реформування системи вищої освіти України, її удосконалення і підвищення рівня якості є найважливішою соціокультурною проблемою, яка значною мірою обумовлюється процесами глобалізації та потребами формування позитивних умов для індивідуального розвитку людини, їі соціалізації та самореалізації у цьому світі. Зазначені процеси диктують необхідність визначення, гармонізації та затвердження нормативно-правового забезпечення в галузі вищої освіти з урахуванням вимог міжнародної та європейської систем стандартів та сертифікації [1].

Аналіз останніх досліджень і публікацій. Сучасні проблеми вищої освіти досліджувались у працях вітчизняних (Н. Бібік, Л. Губерський, В.Захарченко, М.Згуровський, О. Локшина,В.Луговий, О. Овчарук, О. Пометун, Ю. Рашкевич, О. Савченко, Г. Селевко, М. Степко, Ж. Таланова, М. Чобітько, О. Шапран та ін.), так і зарубіжних дослідників (Р. Болестер, Т. Навраксис, П. Рейлі, М. Рейхертс, А. Хербовська та ін.).

Дослідженню професійної підготовки фахівців у вищій освіті присвячені праці В. Байденко, Р. Гуревича, І. Доброскок, М. Євтуха, С. Сисоєвої та ін. Серед пріоритетних напрямів - питання історії й філософії вищої педагогічної освіти (В. Андрущенко, В. Бондар, І. Зязюн, В. Кремень та ін.), перспективні напрями розвитку вищої освіти (I. Бех, Н. Бідюк, С. Гончаренко, С. Мартиненко, Л. Хомич та ін.), формування педагогічної культури студентів упроцесі навчання (I. Андрощук, О. Гомонюк, О. Савченко та ін.) та професійної мобільності (А. Петров, Г. Селевко, Л. Сушенцева та ін.). У наукових дослідженнях значна увага приділяється технологічним аспектам навчально-виховного процесу, особливостям підготовки майбутніх учителів, формуванню їх професійної компетентності (Н. Бібік, С. Кара, О. Снігур та iн.) [4].

Формулювання цілей статті. Мета статті - висвітлити концептуальні напрями розвитку вищої освіти в Україні в умовах євроінтеграції; показати шляхи їх реалізації.

Виклад основного матеріалу. В Україні, як і в інших розвинутих країнах світу, вища освіта визнана однією з провідних галузей розвитку суспільства. Стратегічні напрями розвитку вищої освіти визначені Конституцією України, Законами України "Про освіту”, “Про вищу освіту”, Національною доктриною розвитку освіти, указами Президента України, постановами Кабінету Міністрів України.

Основною метою державної політики в галузі освіти є створення умов для розвитку особистості і творчої самореалізації кожного громадянина України, оновлення змісту освіти та організації освітнього процесу відповідно до демократичних цінностей, ринкових засад економіки, сучасних науково-технічних досягнень [2].

Пріоритетними напрямами державної політики щодо розвитку вищої освіти є: особистісна орієнтація вищої освіти; створення для громадян рівних можливостей у здобутті вищої освіти; постійне підвищення якості освіти, оновлення іiі змісту та форм організації навчально-виховного процесу; запровадження освітніх інновацій та інформаційних технологій; інтеграція вітчизняної вищої освіти до європейського та світового освітніх просторів.

Для реалізації цих напрямів реформування системи вищої освіти України передбачено: перехід до динамічної ступеневої системи підготовки фахівців, що дасть змогу задовольняти можливості особистості в здобутті певного освітнього та кваліфікаційного рівня за бажаним напрямом відповідно до тіі здібностей та забезпечити мобільність на ринку праці. Важливе значення має формування мережі закладів вищої освіти, підвищення освітнього і культурного рівня суспільства, створення умов для навчання протягом усього життя та збереження i примноження національних освітніх традицій.

Реформування вищої освіти України проводиться із врахуванням вимог Міжнародної стандартної класифікації занять (ISCO-88 (МСК3), Міжнародної стандартної класифікації освіти (ISCED-97 (MCKO), Міжнародного стандарту якості серії ISO 9000 та вимог, критеріїв та стандартів, які узгодили країни-учасниці Болонського процесу [3].

Свропейські заклади вищої освіти взяли на себе завдання та головну роль створення Свропейського простору вищої освіти. Стояти осторонь від цього процесу Україна не може. Освіта вже стала одним 3 найважливіших чинників політики. Участь вищої освіти України в Болонських перетвореннях має бути спрямована лише на її розвиток і набуття нових якісних ознак, а не втрату кращих традицій i зниження національних стандартів якості.

Основний зміст Болонської декларації полягає в тому, що країни-учасниці зобов'язалися привести свої освітні системи у відповідність до єдиного стандарту. Болонський процес - один 3 інструментів не лише інтеграції в Свропі і в Свропу, а й інструмент загальної світової тенденції нашого часу - глобалізації. Європейська спільнота має намір зробити внесок у якісну освіту шляхом 


\section{КОНЦЕПТУАЛЬНІ НАПРЯМИ РОЗВИТКУ ВИЩОЇ ОСВІТИ В УКРӒ̈НІ У КОНТЕКСТІ ЄВРОПЕЙСЬКОӤ ІНТЕГРАЦІЇ}

заохочення країн-учасниць до сприяння підвищенню якості власної освіти [5].

Згідно ідей Болонського процесу в Україні необхідно: підвищити якість освітніх послуг; розширити доступ до європейської освіти; сформувати єдиний ринок праці вищої кваліфікації в Європі; розширити мобільність студентів та викладачів; прийняти порівнювану систему ступенів вищої освіти з видачею зрозумілих у всіх країнах Європи додатків до дипломів.

На основі принципів Болонського процесу в Україні введено два цикли навчання. Перший цикл для одержання ступеня бакалавра $з$ тривалістю навчання 3 - 4 роки. Другий цикл - для одержання ступеня магістра (1 - 2 роки навчання після бакалаврату) або для одержання ступеня доктора.

Важливе значення має контроль якості освіти, оцінювання якої буде грунтуватися не на тривалості або змісті навчання, а на тих знаннях, уміннях та навичках, які набули випускники. Оцінку будуть давати незалежні акредитаційні агентства. Також передбачається розвиток мобільності студентів та викладацького складу.

Вища освіта на сучасному етапі повинна грунтуватися на наукових дослідженнях. Викладачі повинні обов'язково мати тему наукових досліджень, пов'язувати іiї з освітнім процесом, залучати студентів до науково-дослідної роботи. Система навчального навантаження грунтується на європейській кредитнотрансферній системі (ЕСTS). Остання передбачає ведення системи обліку навчального навантаження однаково для всіх європейських країн. Введення такої системи є нагальною потребою з огляду на мобільність студентів, необхідність перезарахування результатів навчальної діяльності. Кредити ECTS відображають загальне навантаження студента при вивченні певного курсу або якоїсь його частини. Кредити враховують усі види навчальної роботи (лекції, семінари, лабораторні заняття, заліки, екзамени, практику тощо) і забезпечують уніфікований підхід до визначення трудомісткості освітньої діяльності студентів [3].

Об'єктивні закономірності розвитку суспільства у XXI ст. викликали необхідність науково обгрунтованого розв'язання низки кардинальних проблем. Зокрема, це пошук раціональних схем співвідношення між прискореним зростанням знань, нових технологій і здатністю людей творчо підходити до їх використання. Також необхідно забезпечити оптимальне співвідношення між локальними та глобальними соціально-економічними проблемами, щоб людина, формуючись як патріот своєї країни, відчувала відповідальність за щастя, добробут у всьому світі. У закладах вищої освіти необхідно виробити у майбутнього фахівця здатність ефективно діяти в умовах нових суспільноекономічних реалій (глобалізації, інформатизації, високих технологій) [3].

Виходячи з названих соціальних проблем, постають завдання вироблення нових підходів до модернізації системи освіти у всіх ланках їі функціонування. Вони перспективно визначені в Національній доктрині розвитку освіти. Це зміна змісту навчання, систематичне його оновлення, вироблення в студента розуміння необхідності та уміння навчатися впродовж життя, а також засвоєння суми базових знань.

В інформаційному суспільстві знання стають безпосередньою продуктивною силою. Це потребує вміння все життя набувати нових знань і застосовувати їх. Оволодівши технологією прийняття рішень, свободою вибору, людина стає здатною адаптуватися в умовах постійних змін.

Вимогою часу є утвердження особистісно орієнтованої педагогічної системи у виховному процесі як відображення людиноцентризму в розвитку сучасного світу. Це особливо важливо для України, яка тривалий час терпіла тоталітаризм, авторитаризм. Тепер потрібно робити все можливе, щоб замінити авторитарну педагогіку суб'єктно-суб'єктною моделлю відносин, готувати самодостатніх людей. Вища освіта має готувати людину, органічно адаптовану до життя у світі багатоманітних зв'язків, від контактів 3 найближчим оточенням до глобальних [4].

Глобалізація - це тенденція до єдності світу і загострення в цивілізованих рамках конкуренції між державами-націями. Держава матиме успіх тоді, коли іiі громадяни виявляться здатними до спілкування зі світом.

В умовах євроінтеграції вища освіта має набути інноваційного характеру. Освічена людина повинна бути здатною до інноваційного типу життя й життєдіяльності. Надзвичайно важлива риса способу життя людини у XXI ст. - змінність, динамізм. Звідси - необхідність формувати особистість, налаштовану на сприйняття зміни як природної норми.

Суспільство знань, у якому відбувається формування особистості, вимагає загальної педагогізації, упровадження масової педагогічної культури. Необхідно ліквідувати психологопедагогічну неграмотність та передбачати педагогічні наслідки будь-якої суспільнополітичної чи соціально-економічної дії.

XXI ст. висуває нові вимоги до вищої освіти, 


\section{КОНЦЕПТУАЛЬНІ НАПРЯМИ РОЗВИТКУ ВИЩОЇ ОСВІТИ В УКРАЇНІ У КОНТЕКСТІ ЄВРОПЕЙСЬКОЇ ІНТЕГРАЦІЇ}

але й надає нові можливості для освітньої діяльності. Передусім це пов'язано із сучасними інформаційними технологіями, комп'ютерною технікою, що використовується і як засіб набуття комп'ютерної грамотності, і як засіб вивчення предметів, і як шлях до знань і досвіду людства, і як засіб дистанційного навчання. Органічною стає потреба в узаконенні множинності освітніх траєкторій, варіативності методик (кейс-системи, тренінгові технології, тьюторство, фасилітація, модерація).

Вища освіта у XXI ст. - це не лише надання знань і вихованості особистості. Освіта в добу глобалізації та високих технологій - це чинник соціальної стабільності, економічного добробуту, конкурентоспроможності й національної безпеки. Важливим напрямом розвитку вищої освіти $є$ поціновування гідності педагога, науковця, інтелектуала як одна з вимог філософії XXI ст.

Висновки. Отже, важливим напрямом сучасної освітньої парадигми, зумовленою новою філософією вищої освіти, є підготовка фахівця нової генерації, який би володів достатнім тезаурусом на початковій стадії своєї практичної діяльності й мав належну базу знань для успішної орієнтації в будь-якій ситуації протягом усього періоду активного життя. Визначальними напрямами розвитку вищої школи є моральна довершеність майбутніх фахівців, надійний знаннєвий багаж, високий рівень інтелектуального розвитку, володіння методами самостійної пізнавальної діяльності, прагнення досягти успіху й уміння будувати міжособистісні стосунки.

Це має бути фахівець з грунтовним багажем знань, практичних умінь, професійних навичок, добре підготовлений до повноцінного виконання посадових обов'язків. Крім того, випускник має винести зі стін навчального закладу високу культуру, комунікабельність, здатність неперервно поповнювати свої знання самостійно.

Важливим напрямом діяльності вищої школи в умовах євроінтеграції $є$ наявність у випускників прагнення досягти успіху, орієнтація на високі результати, перманентне бажання діяти й досягати мети.

Згідно законів Болонського процесу важливим чинником розвитку вищої освіти у новому тисячолітті є створення Свропи Знань.

Перспективи подальших розвідок у даному напрямі. Перспективи подальших розвідок щодо концептуальних напрямів у контексті європейської інтеграції ми вбачаємо у вивченні інноваційних підходів до організації освітнього процесу в закладах вищої освіти.

\section{ЛІТЕРАТУРА}

1. Вища освіта в Україні: навч. посібник / В.Г. Кремінь, С.М. Ніколаєнко, М.Ф. Степко та ін. Київ, 2005. 327 с.

2. Закон України “Про вищу освіту”. URL: http:/ /sfs.gov.ua/diyalnist-/zakonodavstvo-pro-diyalnis/ zakoni-ukraini/65715.html

3. Кузьмінський А.I. Педагогіка вищої школи: навч. посібник. Київ, 2005. 486 с.

4. Рашкевич Ю.М. Болонський процес: історія та перспективи. Освітня аналітика України. 2018. №3. С. 5-15.

5. Рашкевич Ю.М. Болонський процес та нова парадигма вищоїосвіти: монографія. Львів, 2014. 168 с.

\section{REFERENCES}

1. Vyshcha osvita v Ukraini: navch. posibnyk / V.H.Kremin, S.M.Nikolaienko, M.F.Stepko ta in. [Higher education in Ukraine: study. manual]. Kyiv, 2005. 327 p. [in Ukrainian].

2. Zakon Ukrainy "Pro vyshchu osvitu" [Law of Ukraine "On Higher Education"]. Available at: http:/ /sfs.gov.ua/diyalnist-/zakonodavstvo-pro-diyalnis/ zakoni-ukraini/65715.html[in Ukrainian].

3. Kuzminskyi, A.I. (2005). Pedahohika vyshchoi shkoly: navch. posibnyk [Higher Education Pedagogy: Educ. manual]. Kyiv, 486 p.[in Ukrainian].

4. Rashkevych, Yu.M. (2018). Bolonskyi protses: istoriia ta perspektyvy [The Bologna Process: History and Prospects]. Educational analytics of Ukraine. No.3, pp. 5-15. [in Ukrainian].

5. Rashkevych, Yu.M. (2014). Bolonskyi protses ta nova paradyhma vyshchoi osvity: monohrafiia [The Bologna Process and the New Higher Education Paradigm: a Monograph]. Lviv, 168 p.[in Ukrainian].

Стаття надійшла до редакції 05.07.2019

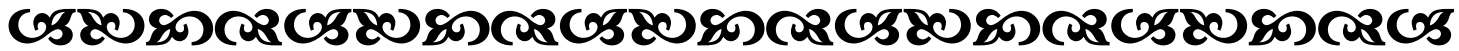

“Визначеність мети - відправна точқа всіх досягненъ”.

$$
\begin{array}{r}
\text { Вільям Клемент Стоун } \\
\text { американський бізнесмен, меиенат }
\end{array}
$$

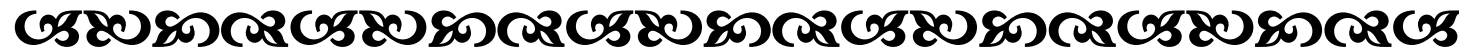

